\title{
Is phytoremediation a sustainable and reliable approach to clean-up contaminated water and soil in Alpine areas?
}

\author{
Jean-Paul Schwitzguébel • Elena Comino • \\ Nadia Plata $\cdot$ Mohammadali Khalvati
}

Received: 12 November 2010 / Accepted: 16 March 2011 /Published online: 5 April 2011

(C) Springer-Verlag 2011

\begin{abstract}
Background, aim and scope Phytoremediation does exploit natural plant physiological processes and can be used to decontaminate agricultural soils, industrial sites, brownfields, sediments and water containing inorganic and organic pollutants or to improve food chain safety by phytostabilisation of toxic elements. It is a low-cost and environment friendly technology targetting removal, degradation or immobilisation of contaminants. The aim of the present review is to highlight some recent advances in phytoremediation in the Alpine context.
\end{abstract}

Responsible editor: Elena Maestri

J.-P. Schwitzguébel $(\varangle)$

Laboratory for Environmental Biotechnology,

EPFL, Station 6,

1015 Lausanne, Switzerland

e-mail: Jean-paul.schwitzguebel@epfl.ch

E. Comino

Land, Environment and Geo-Engineering Department,

Politecnico di Torino,

Corso Duca degli Abruzzi 24,

10129 Turin, Italy

e-mail: elena.comino@polito.it

N. Plata

EPTES Sarl,

Rue de la Madeleine 28,

1800 Vevey, Switzerland

e-mail: Nadia.plata@eptes.com

M. Khalvati

Department of Microbe-Plant Interactions, Helmholtz Zentrum München, German Research Center for Environmental Health, Ingolstädter Landstrasse 1,

85764 Neuherberg, Germany

e-mail: mohammadali.khalvati@helmholtz-muenchen.de
Main features Case studies are presented where phytoremediation has been or can be successfully applied in Alpine areas to: (1) clean-up industrial wastewater containing sulphonated aromatic xenobiotics released by dye and textile industries; (2) remediate agricultural soils polluted by petroleum hydrocarbons; (3) improve food chain safety in soils contaminated with toxic trace elements (As, $\mathrm{Co}, \mathrm{Cr}$ and $\mathrm{Pb}$ ); and (4) treat soils impacted by modern agricultural activities with a special emphasis on phosphate fertilisation. Conclusions, recommendations and perspectives Worlwide, including in Alpine areas, the controlled use of appropriate plants is destined to play a major role for remediation and restoration of polluted and degraded ecosystems, monitoring and assessment of environmental quality, prevention of landscape degradation and immobilisation of trace elements. Phytotechnologies do already offer promising approaches towards environmental remediation, human health, food safety and sustainable development for the 21st century in Alpine areas and elsewhere all over the world.

Keywords Phytoremediation - Alpine regions . Contaminated soils $\cdot$ Industrial wastewater $\cdot$ Petroleum hydrocarbons · Sulphonated aromatic compounds · Trace elements $\cdot$ Mycorrhizal fungi

\section{Background, aim and scope}

Phytotechnologies can be defined as the use of plants to remediate, treat, stabilise or control contaminated substrates, and phytoremediation is one of these, dedicated to the removal or the destruction of contaminants. Phytoremediation does exploit natural plant physiological processes and can be used to decontaminate agricultural soils, 
industrial sites, brownfields, sediments and water containing metals and/or organic compounds. It is a low-cost and environment friendly technology targetting extraction, degradation or fixation of the contaminants (Schwitzguébel et al. 2009). Similar technologies of ecological engineering or ecoremediation can be used for revegetating degraded land (like quarries, road sides), as well as for removing excessive nutrient loads and cleaning-up wastewater (road runoff, municipal and industrial effluents, surface and seepage water) with soil-plant filters, buffer strips and constructed wetlands (Otto et al. 2008; Bulc and Slak 2009; Vymazal 2009; Borin et al. 2010). Plants represent a more environmentally compatible and less expensive method to site restoration compared to physico-chemical and engineering techniques, even though the time scale required to reach the fixed end-points can become a limiting factor for such ecoremediation approaches (Denys et al. 2006; Komives et al. 2009; Mench et al. 2009, 2010; Vangronsveld et al. 2009). Plants are already cleaning our environment constantly, everywhere, even if we do not recognise or know it. On the other hand, biomass produced on contaminated land can be used as renewable energy source, not competing with food supply and contributing to sustainable land use management (Van Ginneken et al. 2007; Meers et al. 2010). Since plants can also exclude metal or organic contaminants, and thus reduce their transfer to the food chain, phytotechnologies are also offering efficient tools to improve food safety.

The bioavailable fraction of soil contaminants should be considered as the most important one from an ecological, toxicological and health standpoint, and it is determined by the chemical properties of the metal or organic compound, soil and climatic characteristics, ageing processes and biota behaviour. Ageing usually decreases bioavailability, but root exudates, root-induced rhizosphere changes, mycorrhizal fungi and rhizospheric bacteria play a major role in the dynamics and the ability of contaminants to move from soils to plants; vertical and horizontal spreading of contaminants to the surroundings and groundwater will also be affected. The bioavailability of contaminants and their uptake by crop plants are essential parameters for establishing risk-based regulatory guidelines and enhancing food safety (Mench et al. 2009).

A significant part of agricultural land in Europeincluding many Alpine territories-is contaminated with heavy metals and organic chemicals, some of which still in agricultural use. Food produced on those sites can pose human health risks: several important agro-ecosystem functions are impaired and such sites can be sources of food contamination and further pollution via re-spreading to the surroundings by wind and water erosion or leaching into groundwater. Due to more severe legislation in many countries, contaminated agricultural soils still under pro- duction and many additional areas, which until now have not been subject to regulation, will be taken out of food production and become marginalised. There are two alternatives to deal with such soils: they have to be set aside or cleaned. Conventional remediation methods like landfilling or excavation and extraction impose high costs, destroy soil structure, and diminish soil productivity. Sites like these need a sustainable plant cover to prevent reentrainment of particulates and further contamination of more agricultural land as well as direct impact on local populations. Phytotechnologies can offer a cost-effective in situ alternative for low- or medium-contaminated soils resulting in increased soil fertility (Baker et al. 1994; Vangronsveld et al. 2009; Mench et al. 2010).

Brownfields - contaminated sites around former and present mines, abandoned old industrial sites or ash and slag dumps from coal-fuelled power plants, coal and gas plants, oil-refineries, ammunition plants, military bases, and pesticide tombs, are numerous in Europe, and their restoration for future safe use has become an important issue. An appropriate rehabilitation and sustainable management of contaminated brownfields is thus now a priority. Phytotechnologies are expected to play a major role in the restoration of former industrial areas, but the activities must also include site identification and characterisation, parallel soil treatability tests, as well as field-scale implementation and evaluation (French et al. 2006; Onwubuya et al. 2009; Vangronsveld et al. 2009; Mench et al. 2010). Green plants can also be used to treat freshly dredged polluted sediments, even if this approach is only at its infancy (Bert et al. 2009).

The most significant phytotreatments of soils, sites and brownfields are the following:

- Phytostabilisation, based on the immobilisation of organic and inorganic contaminants by the addition of appropriate soil amendments, the adsorption to plant roots or soil particles, and the precipitation in the root area, thus preventing their migration and decreasing erosion, runoff and leaching (Kumpiene et al. 2007). It also promotes restoration and biodiversity of ecosystems accounting for ecological benefits or the production of industrial crops producing essential oil or fibres. The most effective is the use of indigenous plant species, accustomed to the local climate and soils and not creating adaptation or invasion problems.

- Phytoextraction, based on the absorption of contaminants into roots, then translocation into shoots, followed by harvest and destruction of the plants. Depending on their market value, metals can be recovered from contaminated biomass or ash (Dickinson et al. 2009).

- Phytodegradation and phytotransformation of xenobiotic compounds, exploiting the huge potential and biodiversity 
of plant secondary metabolism (Schwitzguébel et al. 2008).

- Phytostimulation: enhanced microbial metabolism of organic pollutants in plant rhizosphere; plant/microbial interactions are important for such a process (Gaskin and Bentham 2010).

- Hydraulic control of pollutants: the use of phreatophyte trees (poplar, willow and aspen) to transpire large amounts of water and thus limit the transport of groundwater pollutants (Liste and White 2008).

In constructed wetlands, plants are used as part of a managed ecosystem to remove contaminants from aqueous waste streams (Haberl et al. 2003; Imfeld et al. 2009; Vymazal 2009; Vymazal and Kröpfelovà 2009). Alternatively, hydroponic cultures or nutrient film techniques can be used in a process called rhizofiltration or phytofiltration (Schwitzguébel et al. 2008, 2011). Waters under consideration include industrial and domestic wastewater, groundwater and surface water as well as landfill leachates, containing biodegradable or recalcitrant organic compounds, toxic metals and/or radionuclides.

The aim of the present review paper is to highlight some recent advances and case studies where phytoremediation has been or can be successfully applied in the Alpine context to treat: (1) industrial wastewater containing sulphonated aromatic compounds released from synthetic dye and pigments production; (2) agricultural soils polluted by petroleum hydrocarbons; (3) soils contaminated with As, $\mathrm{Co}, \mathrm{Cr}$ and $\mathrm{Pb}$; and (4) soils polluted by modern agricultural activities with a special emphasis on phosphate fertilisation.

\section{Toward the phytotreatment of wastewater from chemical industries}

Due to the proximity and abundance of water and hydroelectric power plants, many industries have been established in Alpine regions, especially in the upper Rhone and Rhine valleys; among others, chemical industries producing fine chemicals like dyes and pigments. To treat effluents released by these industries, often containing recalcitrant compounds, classical wastewater treatment plants are not always efficient, and reliable alternatives are thus needed. More precisely, constructed wetlands and hydroponic systems (rhizofiltration or phytofiltration) are able to remove and degrade many organic pollutants from industrial wastewater (Haberl et al. 2003; Bulc and Ojstrsek 2008; Schwitzguébel et al. 2008, 2011). Both are based on the use of appropriate plant species and offer a low-cost, low-maintenance approach to treat recalcitrant xenobiotic compounds. Before, to be applicable at large scale, however, research and development are needed to choose the most efficient plant species, characterise the detoxification mechanisms, design and size the system and define the optimal operation conditions.

Such an approach has been applied to develop the phytotreatment of synthetic sulphonated aromatic compounds, the parent molecules for a large palette of dyes and an important starting material in their production. Dyes are intentionally designed to be resistant under typical usage conditions, making difficult the treatment of their by-products and of wastewater from production lines. Because they contain at least one sulphonic group and often also varying substitutions such as nitro groups, these chemicals are not uniformly susceptible to biodecolourisation and biodegradation. Effluents from dye, textile and detergent industries, but also leachates from landfills, are thus often contaminated with sulphonated aromatics, giving to these chemicals an actual impact on the environment, especially fresh water (Schwitzguébel et al. 2002). The removal and/or degradation of sulphonated xenobiotics from industrial wastewater thus remains a major challenge, not only because of the colour, but also of recalcitrance and toxicity. Over the last two decades, several physical or chemical treatments have been tested; however, they have major disadvantages, including high cost, low efficiency and inapplicability to a wide variety of dyes, as well as the formation of by-products, creating disposal problems of contaminated wastes. On the other hand, the microbial degradation of synthetic dyes including azo and anthraquinone derivatives often requires unusual catabolic properties rarely found in a single bacterial or fungal species, and the accumulation of dead-end products often occurs (Schwitzguébel et al. 2002). The limited ability of micro-organisms to degrade sulphonoaromatic compounds, and thus to cope with various mixtures of these xenobiotics, limits the efficiency and, therefore, the use of conventional wastewater treatment plants based on activated sludge.

In such a context, the ability of several plant species to remove sulphonated anthraquinones from synthetic wastewater has been tested in hydroponic systems (Aubert and Schwitzguébel 2004). As shown in Table 1, the most promising results were obtained with plants producing natural anthraquinones, like Rheum rabarbarum (rhubarb), especially the Valentine cultivar, or Rumex hydrolapatum and Rumex acetosa (Aubert 2003; Haberl et al. 2003; Aubert and Schwitzguébel 2004). However, the removal of a pollutant from a liquid medium does not mean that it is accumulated and degraded by the plant itself. The next step was thus to investigate any possible adsorption, uptake, metabolism and degradation by plants. As measured by capillary electrophoresis (Aubert and Schwitzguébel 2002), sulphonated anthraquinones were 
Table 1 Removal of sulphonated anthraquinones by different plant species cultivated under hydroponic conditions

\begin{tabular}{|c|c|c|c|c|c|}
\hline Plant species & $\begin{array}{l}\text { AQ-1S } \\
\left(68.8 \mathrm{mg} \mathrm{L}^{-1}\right)\end{array}$ & $\begin{array}{l}\text { AQ-2S } \\
\left(65.7 \mathrm{mg} \mathrm{L}^{-1}\right)\end{array}$ & $\begin{array}{l}\text { AQ-1,5-SS } \\
\left(82.5 \mathrm{mg} \mathrm{L}^{-1}\right)\end{array}$ & $\begin{array}{l}\text { AQ-1,8-SS } \\
\left(82.5 \mathrm{mg} \mathrm{L}^{-1}\right)\end{array}$ & $\begin{array}{l}\text { AQ-2,8-SS } \\
\left(82.5 \mathrm{mg} \mathrm{L}^{-1}\right)\end{array}$ \\
\hline $\begin{array}{l}\text { Control (no plant, } \\
\text { dark) }\end{array}$ & $8-13$ & $12-16$ & $13-19$ & $12-18$ & $6-11$ \\
\hline $\begin{array}{l}\text { Rheum rabarbarum } \\
\text { (Valentine) }\end{array}$ & $78-89$ & $84-94$ & $79-89$ & $79-89$ & $70-82$ \\
\hline $\begin{array}{l}\text { Rheum rabarbarum } \\
\text { (Sutton) }\end{array}$ & $51-63$ & $62-72$ & $53-68$ & $53-69$ & $31-50$ \\
\hline Rumex hydrolapatum & $39-58$ & $69-81$ & $39-56$ & $40-56$ & $40-56$ \\
\hline Rumex acetosa & $44-53$ & $70-75$ & $31-53$ & $39-53$ & $38-47$ \\
\hline Apium graveolens & $53-70$ & $56-69$ & $32-42$ & $31-42$ & $30-40$ \\
\hline
\end{tabular}

The percentage of each sulphonated anthraquinone removed was measured 6 weeks after the simultaneous addition of each sulphonated anthraquinone in the liquid medium at the concentrations indicated and expressed as the minimal and maximal values of three replicates. Details of experimentation as previously described (Aubert 2003; Aubert and Schwitzguébel 2004)

found in leaves of rhubarb (Fig. 1) and R. hydrolapatum (Fig. 2), indicating their uptake and translocation by these plants. As compared to leaf extracts from plants cultivated without sulphonated anthraquinones, new metabolites were found in plants cultivated with these xenobiotics (Figs. 1 and 2), suggesting that at least some of them, if not all, were transformed by both plant species. Furthermore, the profile of metabolites produced depended on the plant used, highlighting the importance of a careful screening of plant species, ecotypes or cultivars before any application of phytoremediation. Enzymatic investigations have been performed to determine if sulphonated anthraquinones might be transformed by enzymes of the classical detoxification pathways in plants. Results obtained with glutathione S-transferases show that this class of enzymes is not significantly involved in the observed metabolism of sulphonated anthraquinones
(Aubert 2003). In contrast, cytochrome P450 monooxygenases are involved in the detoxification of sulphonated anthraquinones (Page and Schwitzguébel 2009a, b) and glycosyl-transferases could also be involved in the next steps of the metabolism of synthetic sulphonated anthraquinones, with possible crosstalks with the metabolism of natural anthraquinones, often glycosylated as well.

Rhubarb is a hardy perennial plant and appears as a promising species in developing new phytotreatments to decontaminate effluents containing sulphonated aromatic compounds. However, before any industrial application, pilot-scale experimentation should be performed to assess the capacity of this plant and of other species producing natural anthraquinones to deal with real effluents at different concentrations and loading rates and to correctly design and size rhizofiltration treatment units.
Fig. 1 Analysis by capillary electrophoresis of rhubarb leaf extracts. Rhubarb was cultivated with or without (blank) sulphonated anthraquinones

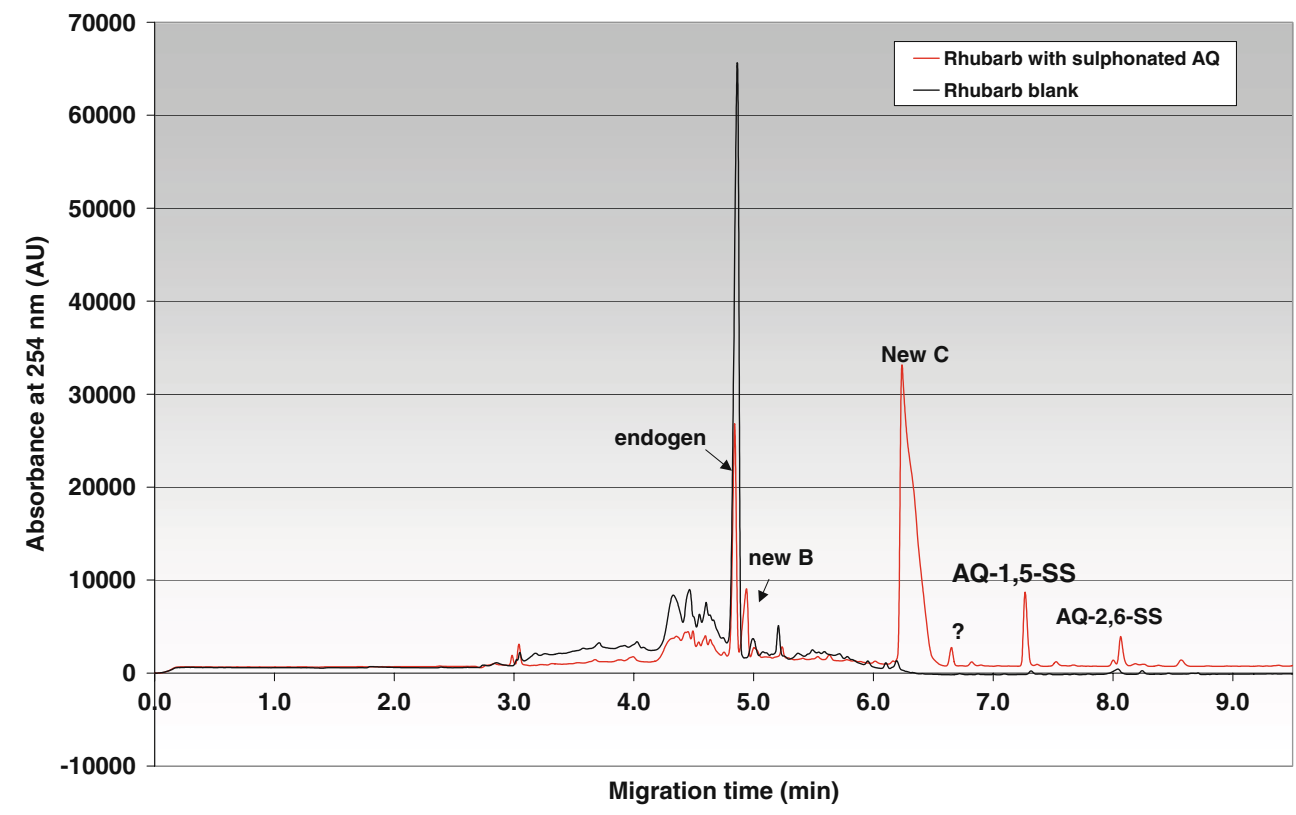


Fig. 2 Analysis by capillary electrophoresis of Rumex hydrolapatum leaf extracts. Rumex was cultivated with or without (blank) sulphonated anthraquinones

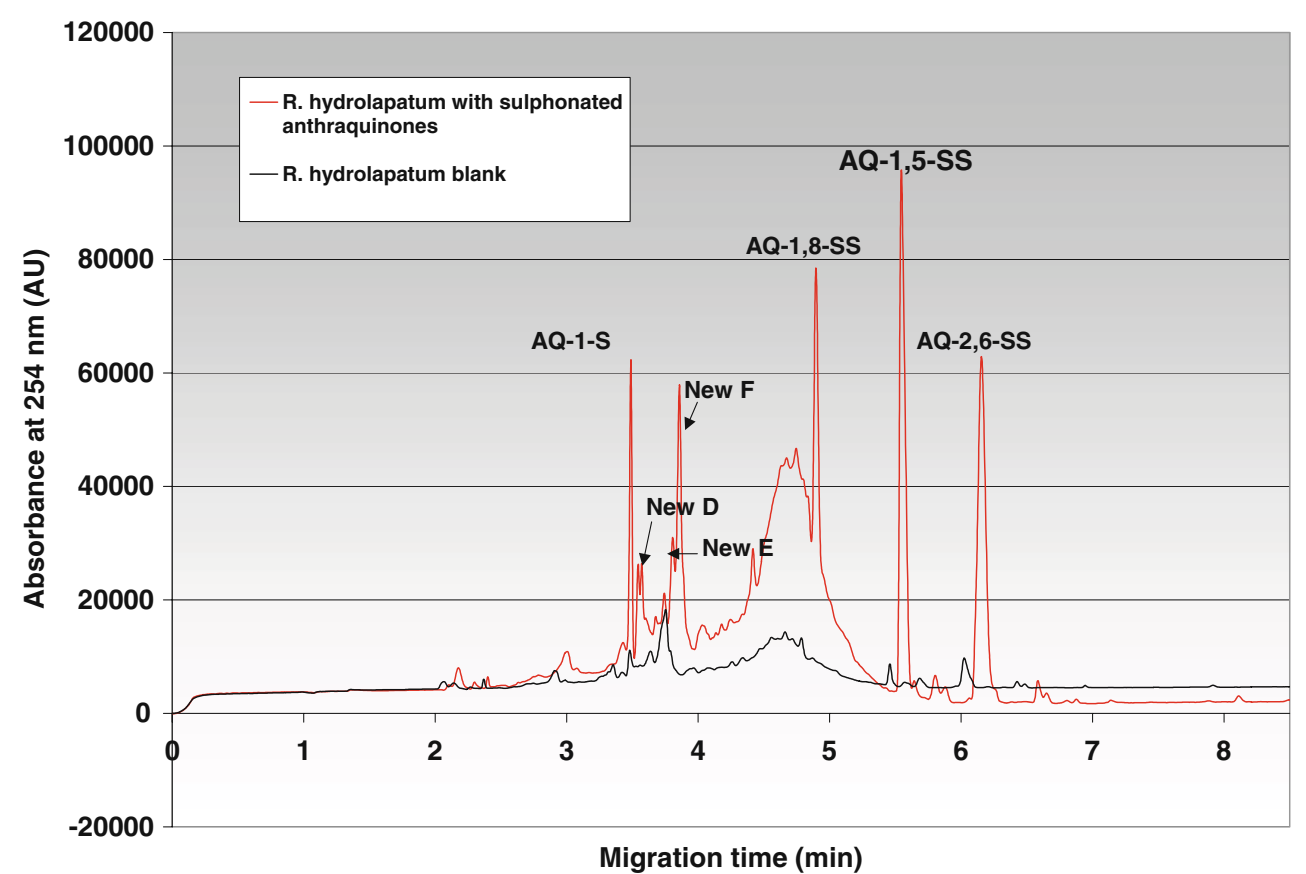

\section{Phytoremediation of a soil polluted by petroleum hydrocarbons: a comprehensive field trial}

A phytoremediation trial was conducted on agricultural soil polluted with petroleum hydrocarbons as a result of a landbased oil well blow-out in Northern Italy in 1994 (Fig. 3). Prior to this trial, the contaminated soil was extensively treated in a biopile to enhance hydrocarbon degradation and then spread back to its original location. The contaminated soil (15 hectares) was divided into parcels representing a modified Latin square design in which phytoremediation and landfarming were applied as replicates (Fig. 4). Local crops were used in the phytoremediation treatment.

The main objectives of the whole field trial were to assess the potential of phytotreatment for the removal of petroleum hydrocarbons under real conditions; compare

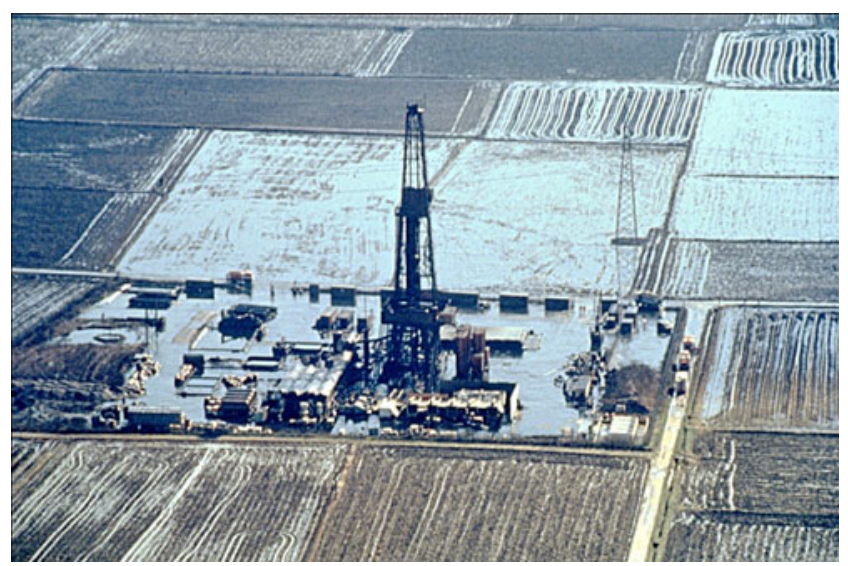

Fig. 3 The spill of a land-based oil well in Northern Italy (March 1994) landfarming treatment and natural attenuation versus phytoremediation in terms of soil remediation; reduce the pollutant's concentration to a level acceptable for an agricultural soil; evaluate the kinetics of the reduction of concentrations of total petroleum hydrocarbons (TPH) and polycyclic aromatic hydrocarbons (PAH); select the crops with the highest ability to reduce crude petroleum hydrocarbons in contaminated soil; assess the potential of uptake and/or enhancement of microbial activities of each plant species in terms of remediation of contaminated soils. A complementary study was conducted in greenhouse to compare results obtained in the field and in a more controlled environment, since temperature, humidity and light parameters are set under greenhouse conditions (Zabludowska et al. 2009). Here, we report on the first three growing seasons (summer 1998, winter 1998-99, and summer 1999), when 11 agricultural species were planted. Plants selected for summer seasons were alfalfa, fescue, clover, corn, ryegrass, sorghum and soya. Plants selected for the winter season were fescue, rape, ryegrass, rye, vetch and triticale. Landfarming treatment consisted of periodic tilling of parcels. Furthermore, the study included the assessment of natural attenuation (weedy areas) which consisted in weeds growing naturally between planted parcels (weed growth, no crops, no tilling).

From each parcel including landfarming and weedy areas, TPH were extracted using supercritical fluid extraction and analysed by gas chromatography coupled with flame ionisation detector. Accelerated solvent extraction was used to extract 35 individual PAH from soil, while for plants, Soxhlet extraction method was used. PAH in soils and in plants were analysed using gas chromatography 
Fig. 4 Scheme and aerial picture of the contaminated soil divided according to the Latin square statistical model
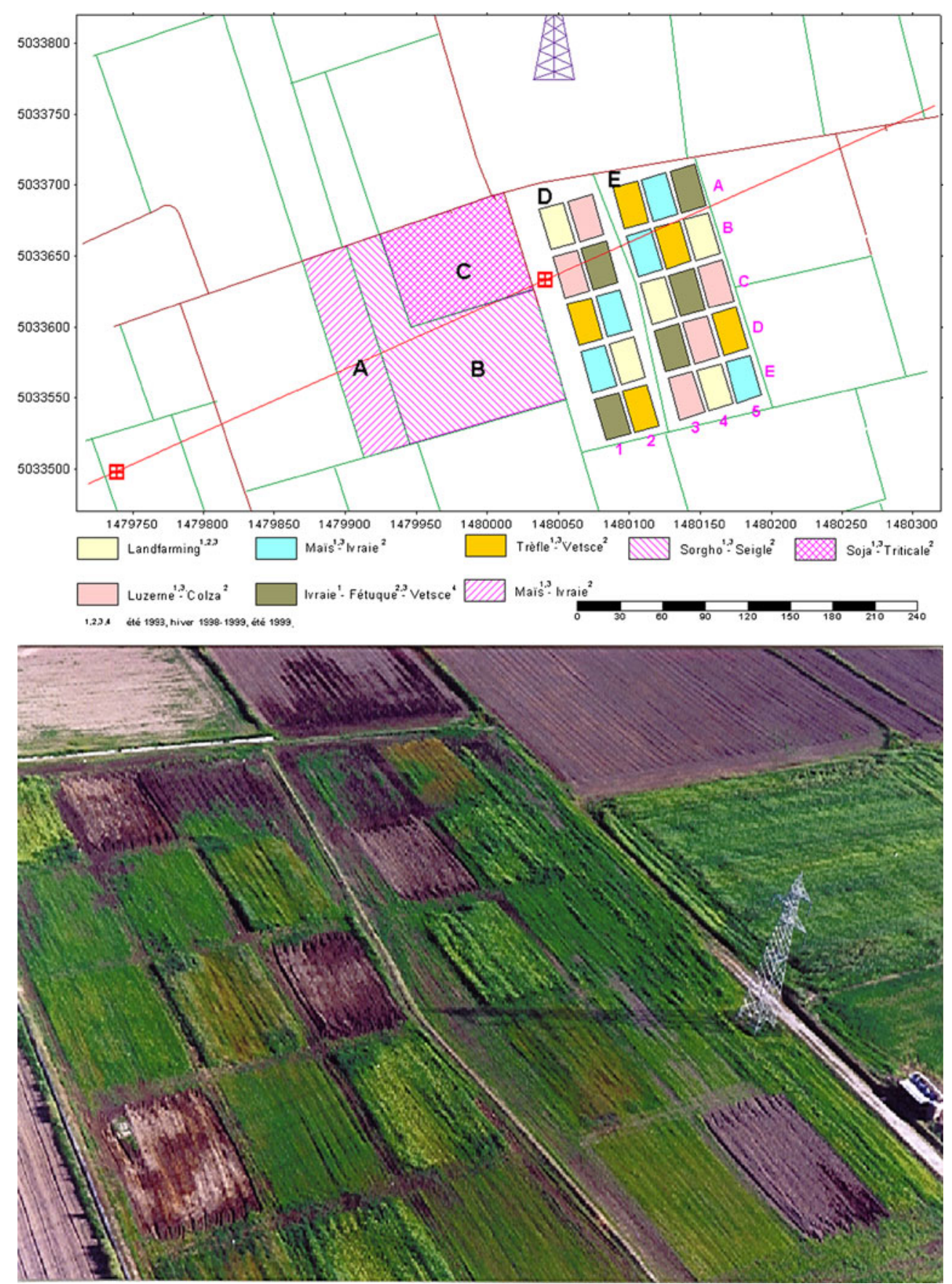

coupled with mass spectrometry. Different statistical treatments were applied in this study; among them are analysis of variance (ANOVA), regression, linearity, parallelism, homogeneity of variance and Student tests. The lack of homogeneity of the soil in the field was also statistically established and coincided with the heterogeneity of plants growth in the same parcel. Details of the experimentation and of statistics are available elsewhere (Plata-Chebbah 2000).

Results obtained during the first summer season indicated that the start of the decontamination process was long and slow. Indeed, soil TPH and PAH concentrations decreased throughout planted, landfarmed parcels and natural attenuation areas, but significantly only with maize and red clover. Average reduction in soil TPH ranged from 721 to $2,849 \mathrm{~kg} \mathrm{ha}^{-1}$ (Table 2). Reduction in soil PAH from the site was between 1.3 and $12 \mathrm{~kg} \mathrm{ha}^{-1}$. During this season, all the agricultural plants underwent stress and exhibited reduced growth, reduced size and yellow colour (Plata-Chebbah 2000).

During the winter season, the rate of soil TPH decrease was significantly greater in cultivated parcels and weedy areas than in landfarmed parcels (Table 2). Reduction in soil TPH from the site ranged from 1,644 (landfarming) to 
Table 2 Removal of TPH and PAH from contaminated soil (mean values of 3-5 parcels sampling)

\begin{tabular}{|c|c|c|c|c|c|c|}
\hline Season & $\begin{array}{l}\text { Initial TPH } \\
\left(\mathrm{mg} \mathrm{kg}^{-1}\right)\end{array}$ & $\begin{array}{l}\text { Final TPH } \\
\left(\mathrm{mg} \mathrm{kg}^{-1}\right)\end{array}$ & $\begin{array}{l}\text { Removed TPH } \\
\left(\mathrm{kg} \mathrm{ha}^{-1}\right)\end{array}$ & $\begin{array}{l}\text { Initial PAH } \\
\left(\mu \mathrm{gg}^{-1}\right)\end{array}$ & $\begin{array}{l}\text { Final PAH } \\
\left(\mu \mathrm{g} \mathrm{kg}^{-1}\right)\end{array}$ & $\begin{array}{l}\text { Removed PAH } \\
\left(\mathrm{kg} \mathrm{ha}^{-1}\right)\end{array}$ \\
\hline \multicolumn{7}{|l|}{ Summer 98} \\
\hline Alfalfa & 3,308 & 2,405 & 2,168 & 6,329 & 4,960 & 3.3 \\
\hline Maize & 3,235 & 2,227 & 2,419 & 6,680 & 4,017 & 12.0 \\
\hline Red clover & 3,414 & 2,227 & 2,849 & 8,687 & 4,373 & 10.4 \\
\hline Ryegrass & 3,751 & 3,451 & 721 & 8,351 & 6,655 & 4.1 \\
\hline Land farming & 3,322 & 2,681 & 1,538 & 6,846 & 6,298 & 1.3 \\
\hline \multicolumn{7}{|l|}{ Winter 98-99 } \\
\hline Fescue & 3,134 & 1,144 & 4,777 & 6,855 & 3,960 & 6.9 \\
\hline Rape & 2,403 & 908 & 3,588 & 4,183 & 1,953 & 5.4 \\
\hline Rye & 3,055 & 1,208 & 4,432 & 5,784 & 5,037 & 1.8 \\
\hline Ryegrass & 2,687 & 1,081 & 3,854 & 6,258 & 2,785 & 8.3 \\
\hline Triticale & 4,202 & 1,930 & 6,478 & 6,317 & 5,794 & 1.6 \\
\hline Vetch & 2,152 & 765 & 3,330 & 5,224 & 2,916 & 5.9 \\
\hline Weed & 2,440 & 701 & 4,173 & 5,213 & 1,692 & 8.5 \\
\hline Land farming & 1,716 & 1,031 & 1,644 & 4,428 & 2,156 & 5.5 \\
\hline \multicolumn{7}{|l|}{ Summer 99} \\
\hline Alfalfa & 1,786 & 861 & 2,221 & 3,673 & 2,273 & 3.4 \\
\hline Fescue & 2,055 & 826 & 2,950 & 3,861 & 2,408 & 3.5 \\
\hline Maize & 2,932 & 561 & 5,692 & 4,100 & 1,927 & 5.2 \\
\hline Red clover & 1,564 & 677 & 2,127 & 4,442 & 2,720 & 3.7 \\
\hline Sorghum & 2,749 & 486 & 5,431 & 5,230 & 1,829 & 8.2 \\
\hline Soya & 2,952 & 1,155 & 4,313 & 3,432 & 1,201 & 7.0 \\
\hline Weed & 2,507 & 472 & 4,885 & 3,467 & 1,703 & 6.1 \\
\hline Landfarming & 1,009 & 735 & 104 & 2,558 & 1,634 & 2.2 \\
\hline
\end{tabular}

$6,478 \mathrm{~kg} \mathrm{ha}^{-1}$ (triticale). Soil PAH concentrations decreased in planted and landfarmed parcels, as well as in weedy areas. However, the smallest quantities of soil PAH removed were observed for rye and triticale, and the highest for ryegrass and weed. The growth of crop plants was less affected than during the first season (PlataChebbah 2000).

During the second summer season, the concentration of soil TPH and PAH only slightly decreased in landfarmed parcels (Table 2). The average removal of TPH was statistically significant for almost all other conditions and ranged from 2,127 (red clover) to 5,692 $\mathrm{kg} \mathrm{ha}^{-1}$ (maize) in planted parcels, whereas it was only $104 \mathrm{~kg} \mathrm{ha}^{-1}$ in landfarmed parcels. The removal of soil PAH ranged from 2.2 (landfarming) to $8.2 \mathrm{~kg} \mathrm{ha}^{-1}$ (sorghum). The reduction in soil TPH concentration coincided with an increased plant growth, as compared to both previous seasons (PlataChebbah 2000).

In parallel alfalfa, clover and fescue (same seeds stock as that used on the contaminated site) were grown in greenhouse environment, in soils from the contaminated site. The results obtained showed that plants grown in greenhouse conditions had a more positive effect on the rate of soil TPH and PAH reduction and plant PAH uptake than those grown under field conditions (Plata-Chebbah 2000). Thus, any extrapolation of phytoremediation results obtained in a greenhouse (reduced scale) to the field (full scale) must be made cautiously, as all the environmental conditions that affect the outcome of field studies do not prevail in greenhouse conditions (Euliss et al. 2008; Zabłudowska et al. 2009).

During the three growing seasons, the very low plant PAH concentration (230-860 $\mathrm{ng} \mathrm{g}^{-1}$ shoot DW) appeared to be a function of soil PAH concentrations. Plant PAH concentrations were thus the highest during the first season and lowest during the third season being however in the same order of magnitude as that of the control plants (not shown). Parallel determinations of PAH concentrations in the plants and $\mathrm{PAH}$ degradation rates in the soil indicated that the degradation of PAH (mostly 2-4 rings: naphthalene, phenanthrene, dibenzothiophene, pyrene, fluoranthene and chrysene) was due to rhizospheric bacteria, and that plants decisively improved their growth and working conditions, as already shown by other studies (Nedunuri et al. 2000; Huang et al. 2005; Denys et al. 2006; Liste and Prutz 2006; Palmroth et al. 2006; Rezek et al. 2008; Gurska 
et al. 2009; Gaskin and Bentham 2010). In contrast, the capacity of plant roots to take up PAH from soil appears to be limited (Gao and Ling 2006; Lin et al. 2007; Gao and Collins 2009; Xu et al. 2009).

When crop plants were cultivated on contaminated soils, TPH were degraded more rapidly than under landfarming conditions, which could be attributed to the positive effects of plants on rhizospheric micro-organisms and to the ploughing up of dirtier soils from lower soil layers (Huang et al. 2004, 2005; Keller et al. 2008). Phytoremediation treatment, especially in the case of maize and sorghum, was much more efficient than landfarming and better than natural attenuation as a facilitator of soil hydrocarbon degradation. The crop rotation maize/ryegrass was found to be the most efficient for the removal of petroleum hydrocarbon from soil (Plata-Chebbah 2000).

The phytoremediation trial began in 1998 and ended in 2004. Afterwards, the soil was clean enough to be reallocated to agriculture. It thus appears that crop plant cultivation and rotation combined with appropriate monitoring for less than a decade is a successful approach to the remediation of hydrocarbon-polluted agricultural soils, even under Alpine conditions.

\section{Soil contamination by $\mathrm{As}, \mathrm{Co}, \mathrm{Cr}$ and $\mathrm{Pb}$ in an Alpine territory used for crop cultivation}

Heavy metal contamination of soils is a worldwide concern, since forage plants and/or food crops are often still cultivated there (Nehnevajova et al. 2005; Quartacci et al. 2006; Kidd et al. 2007; Nehnevajova et al. 2007, 2009; Comino et al. 2009). When present in soil and water, metals can accumulate in living organisms, enter in food chain and affect human health, due to their toxicity. Phytomanagement of metal-contaminated agricultural land is nowadays an interesting approach to either extract or immobilise metals (Fitz and Wenzel 2002; Garcia et al. 2005; Remon et al. 2005; Grispen et al. 2006; Hartley and Lepp 2008; Hernandez-Allica et al. 2008; Verkleij 2008; Butcher 2009; Dickinson et al. 2009; Kidd et al. 2009; Marques et al. 2009a; Memon and Schröder 2009; Pedron et al. 2009; Robinson et al. 2009; Fässler et al. 2010).

A study was initiated because many soils utilised for agriculture, landfarming, grazing and green areas in Alpine areas are often contaminated by metal(loid)s, for example, in Northern Italy (Fig. 5). Many of them can be accumulated and eventually concentrated in the edible parts of crops, depending on their speciation, solubility and bioavailability and by the ability of a crop to take up the essential and non-essential elements and translocate them to the target organs (Burgos et al. 2008; Clemente et al. 2008; Dessureault-Rompre et al. 2008; Almendras et al. 2009;
Quartacci et al. 2009). Metals can be absorbed by plants, wildlife and people through the food they eat. They can also be absorbed by drinking contaminated water. Some heavy metals can also be concentrated (biomagnification) when predator animals eat prey animals as part of the food chain.

The aim of the experimentation was to study the accumulation and translocation of arsenic (As), chromium $(\mathrm{Cr})$, cobalt $(\mathrm{Co})$ and lead $(\mathrm{Pb})$ in plants used as grazing crops or as cover plants to create public open space and parkland. The target of this research was double: first to measure the amount of these elements accumulated in plants (food/feed safety), then to evaluate the capacity of plants to remove metals from soil (phytoextraction). From the results obtained, the risk of food chain contamination and the potential for soil phytoremediation could be assessed. Experimentation was done in laboratory by creating the conditions of a natural site.

The soil was collected at Monteu Roero, a suburban area, south west of Torino, Piedmont Region, Italy (point A in Fig. 5). Composite soil sample was collected from the surface to a depth of $20 \mathrm{~cm}$, air dried, homogenised and analysed for granulometry. The textural analysis showed the following composition, $80.8 \%$ fine sand and $19.2 \%$ grit. The high level of fine sand indicated that this soil could be classified as sandy soil. The soil was analysed for basic chemical-physical properties and for the $\mathrm{As}, \mathrm{Cr}, \mathrm{Co}$ and $\mathrm{Pb}$ concentrations (Table 3).

The soil was spiked with four different concentrations of metal(oid)s (Table 4), whereas one soil sample did not receive any metal (control). Concentrations were $1 \times, 10 \times$, $20 \times$ and $50 \times$ the Italian standard limit for discharging in superficial water bodies [Italian Environmental Code Dlgs $152 / 1999$ ] because in this area, most of the water discharge is on soil surface.

Since it is always more appropriate to use local species for phytoremediation than exotic plants (Yoon et al. 2006; Antosiewicz et al. 2008; Barrutia et al. 2009; Marques et al. 2009 b), seeds of plants characteristic of this area were chosen: Medicago sativa (alfalfa), Trifolium incarnatum (red clover) and a mix of seeds for forage. Alfalfa has the capacity to accumulate metal(oid)s above the tolerance levels of other plants and has the characteristics required by a plant for the extraction from contaminated water and soil (Peralta-Videa et al. 2001). Red clover was selected because of its use as a cover plant to create space/parkland and for its importance as a grazing crop. The mix for forage is made up of eight types of seeds: Lolium perenne Livree 26\%; Lolium multiflorum L. 15\%; Trifolium pratensis 13\%; Glomerata amba 11\%; Festuca arundinacea Demeter 11\%; Dactylis phleum Pratense climax 10\%; Lotus corniculatus 7\%; and Trifolium repens Huia 7\%. It was decided to analyse the capacity to absorb the metals from this composition because it is an ideal grazing/cover plants 


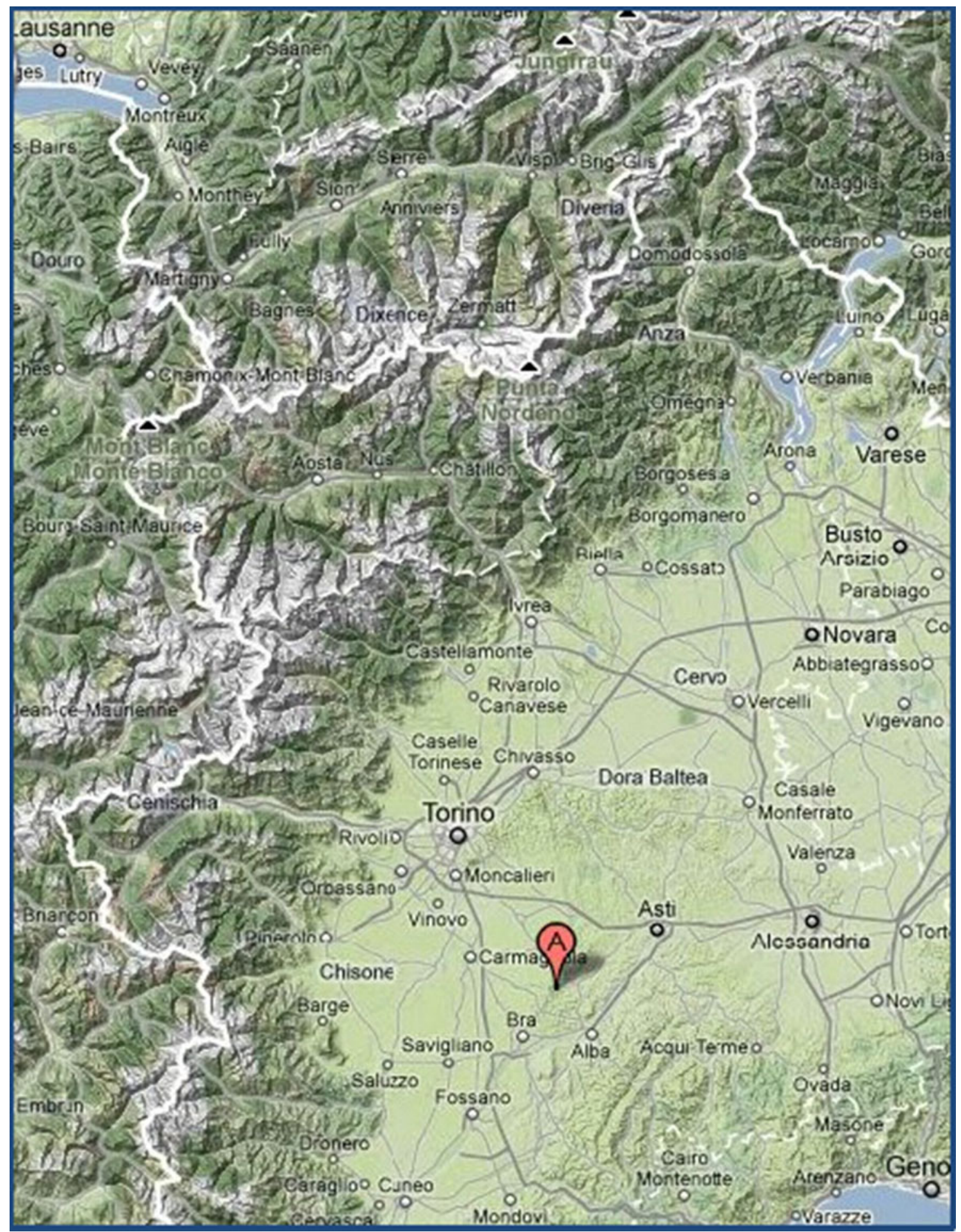

Fig. 5 Polluted area where carried out the idea of the project and where the soil has been collected for the experimental test (Monteu Roero)

mix. On the other hand, co-planting has been reported to be at least as efficient as mono-cropping to remove $\mathrm{Cd}$ and $\mathrm{Zn}$ from contaminated soils (Jiang et al. 2010).

Details of the methodology used have been described elsewhere (Comino et al. 2009). To evaluate the phytoextraction potential of plants as well as the risk of food chain contamination, metal concentration in roots and shoots were measured; and the bioconcentration factor $(\mathrm{BCF}$, the ratio of metal concentration in plant roots and in soil) as well as the translocation factor (TF, the ratio of metal concentration in plant shoots and in roots) were calculated (Table 5). 
Table 3 Main characteristics of soil (Monteu Roero $(\mathrm{CN})$, Italy)

At the end of the study period (6 months), the effect of metals on plants was visible. In fact, change in colour and a reduced development of the plant were the first indicators of the presence of $\mathrm{As}, \mathrm{Co}, \mathrm{Cr}$ and $\mathrm{Pb}$, in agreement with previous studies concerning the effect of heavy metals on plants (Cheng 2003). The growth of T. incarnatum was reduced and the plant developed thick white spots on leaves; this phenomenon was also observed in $M$. sativa and in the mix.

In most cases, the concentrations of $\mathrm{As}, \mathrm{Cr}, \mathrm{Co}$ and $\mathrm{Pb}$ were low in the shoots and higher in the roots. In $M$. sativa, a low accumulation of As was observed, but only when $500 \mu \mathrm{g} \mathrm{As} \mathrm{L}^{-1}$ were added, and TF values reached a value of 1 (Table 5). The concentration of $\mathrm{Co}$ in shoots ranged from 0.06 to $1.68 \mu \mathrm{g} \mathrm{kg}^{-1} \mathrm{DW}$, depending on the concentration of spiked $\mathrm{Co}$, with an increased $\mathrm{TF}$ value as a function of added concentration. Chromium concentrations ranged from 0.7 to $1.5 \mu \mathrm{g} \mathrm{kg}^{-1} \mathrm{DW}$ in shoots, and from 4.6 to $16 \mu \mathrm{g} \mathrm{kg}^{-1} \mathrm{DW}$ in roots, with low TF values (Table 5). Low TF values were also observed for $\mathrm{Pb}$.

Chromium was the metal that was the most accumulated by $T$. incarnatum, reaching values from 1.2 to $7 \mu \mathrm{g} \mathrm{kg}^{-1}$ DW in shoots and from 3.6 to $10.4 \mu \mathrm{g} \mathrm{kg}^{-1} \mathrm{DW}$ in roots, with TF values above 1 for CII and CIII (Table 5). In $T$. incarnatum, As was more accumulated in shoots $\left(0.67 \mu \mathrm{g} \mathrm{kg}^{-1} \mathrm{DW}\right)$ than in roots $\left(0.58 \mu \mathrm{g} \mathrm{kg}{ }^{-1} \mathrm{DW}\right)$, when added concentrations were $\mathrm{CI}$ or CII, showing TF values $>1$ in any case. The accumulation of $\mathrm{Pb}$ varied from 0.8 to $2.6 \mu \mathrm{g} \mathrm{mg}^{-1} \mathrm{DW}$ for both shoots and roots, with TF values from 0.63 to 1.01 . Cobalt accumulation varied from 0.27 to $4.16 \mu \mathrm{g} \mathrm{kg}^{-1} \mathrm{DW}$ in shoots and from 1.05 to $3.8 \mu \mathrm{g} \mathrm{kg}^{-1} \mathrm{DW}$ in roots, with TF usually higher than 1 (Table 5).

Plant species present in the mix for forage accumulated $\mathrm{Cr}$ in roots with concentrations up to $106.3 \mu \mathrm{g} \mathrm{kg}^{-1} \mathrm{DW}$, but seemed unable to accumulate significantly As, Co and $\mathrm{Pb}$. In most cases, the translocation to shoots remained low (Table 5).

Arsenic, $\mathrm{Co}, \mathrm{Cr}$ and $\mathrm{Pb}$ were accumulated mostly in roots, but the $\mathrm{BCF}$ remained very low for alfalfa and red clover for most concentrations tested, indicating that these elements did not exceed the respective soil level (Table 5). For the forage mix, the BCF remained low, except for $\mathrm{Co}$, but the translocation of this element to shoots was low.

Even if soil concentrations of added $\mathrm{As}, \mathrm{Co}, \mathrm{Cr}$ and $\mathrm{Pb}$ were rather high (CIII, CIV), alfalfa, red clover and the mix for forage did not accumulate significantly these toxic elements. However, results need to be confirmed in the field, but all tested plants should be suitable for forage. This feature is important when considering the entire food chain from the soil where these forage crops are grown to animals and humans. In contrast, these plants did not appear to be suitable for phytoextraction of these elements, since concentrations in shoots remained low. This case study highlights that small scale tests are needed to check if and where pollutants are accumulated in plants before selecting the most appropriate species for food chain safety or phytoremediation.

\section{Soil pollution by modern agricultural activities and the role of microbes association to improve soil quality}

Over the last decades, the use of chemical fertilisers including phosphorus has significantly increased to enhance crops yield. This fertilisation has also led to the accumulation of inorganic elements in soils, often causing environmental concerns like eutrophication of surface water.
Table 4 Metal concentrations added in Rorison's solution to irrigate soil $(\mathrm{CI}=$ Italian standard limit for discharging in superficial water bodies [Dlgs 152/ 1999]

\begin{tabular}{lcccc}
\hline Metals & $\mathrm{CI}\left[\mu \mathrm{g} \mathrm{L}^{-1}\right]$ & $\mathrm{CII}\left[\mu \mathrm{g} \mathrm{L}^{-1}\right]$ & $\mathrm{CIII}\left[\mu \mathrm{g} \mathrm{L}^{-1}\right]$ & $\mathrm{CIV}\left[\mu \mathrm{g} \mathrm{L}^{-1}\right]$ \\
\hline $\mathrm{As}$ & 10 & 100 & 200 & 500 \\
$\mathrm{~Pb}$ & 10 & 100 & 200 & 500 \\
$\mathrm{Co}$ & 50 & 500 & 1,000 & 2,500 \\
$\mathrm{Cr}$ & 50 & 500 & 1,000 & 2,500 \\
\hline
\end{tabular}


Table 5 Bioconcentration factor (BCF) and translocation factor (TF) calculated for As, Co, $\mathrm{Cr}, \mathrm{Pb},[\mathrm{BCF}=$ metal concentration ratio of plant roots to soil], $[\mathrm{TF}=$ metal concentration ratio of plant shoots to roots]

\begin{tabular}{llllllllll}
\hline BCF & & & & & TF & & & & \\
\hline Alfalfa & As & Co & Cr & Pb & Alfalfa & As & Co & Cr & Pb \\
Control & 0.04 & 0.06 & 0.08 & 0.04 & Control & 1.00 & 0.07 & 0.08 & 0.15 \\
CI & 0.04 & 0.13 & 0.08 & 0.04 & CI & 1.00 & 0.06 & 0.14 & 0.36 \\
CII & 0.04 & 0.13 & 0.07 & 0.02 & CII & 1.00 & 0.24 & 0.15 & 0.43 \\
CIII & 0.03 & 0.17 & 0.08 & 0.03 & CIII & 1.00 & 0.49 & 0.29 & 0.36 \\
CIV & 0.14 & 0.30 & 0.31 & 0.12 & CIV & 0.35 & 0.80 & 0.04 & 0.17 \\
Red clover & As & Co & Cr & Pb & Red clover & As & Co & Cr & Pb \\
Control & 0.03 & 0.01 & 0.02 & 0.01 & Control & 1.38 & 1.63 & 0.83 & 7.50 \\
CI & 0.04 & 0.10 & 0.07 & 0.04 & CI & 1.00 & 0.26 & 0.35 & 1.01 \\
CII & 0.03 & 0.12 & 0.07 & 0.06 & CII & 1.26 & 2.07 & 1.11 & 0.78 \\
CIII & 0.05 & 0.14 & 0.10 & 0.05 & CIII & 1.51 & 1.37 & 1.11 & 0.63 \\
CIV & 0.07 & 0.19 & 0.14 & 0.06 & CIV & 1.12 & 1.11 & 0.12 & 1.01 \\
Forage mix & As & Co & Cr & Pb & Forage mix & As & Co & Cr & Pb \\
Control & 0.04 & 0.22 & 0.36 & 0.01 & Control & 1.00 & 0.39 & 0.11 & 3.30 \\
CI & 0.06 & 1.70 & 0.30 & 0.07 & CI & 0.44 & 0.14 & 0.13 & 0.20 \\
CII & 0.16 & 0.52 & 0.58 & 0.16 & CII & 0.25 & 0.30 & 0.31 & 0.65 \\
CIII & 0.21 & 4.44 & 0.83 & 0.16 & CIII & 0.47 & 0.66 & 0.25 & 0.94 \\
CIV & 0.31 & 2.38 & 1.45 & 0.29 & CIV & 0.43 & 0.41 & 0.23 & 1.07 \\
\hline
\end{tabular}

Due to the low phosphate (P) uptake by crops, farmers have repeatedly applied $\mathrm{P}$ to realise high crop yields regardless of the large amounts already present in soils. In some Western European countries, accumulation exceeds $4 \mathrm{~kg} \mathrm{Pha}{ }^{-1} \mathrm{y}^{-1}$, but this value swells up to $16 \mathrm{~kg} \mathrm{Pha}^{-1} \mathrm{y}^{-1}$, when $\mathrm{P}$ applied as animal manure is also considered. Global supply of economically exploitable $\mathrm{P}$ present in rock, required for the manufacturing of fertilisers is limited and a non-renewable resource, future agricultural strategies should focus on maximising $\mathrm{P}$ use efficiency with minimum adverse environmental impact (Frossard et al. 2000). Values of extractable (by ammonium lactate) $\mathrm{P}$ accumulation as high as 400 to $700 \mathrm{mg} \mathrm{kg}^{-1}$ soil have been reported (Singh et al. 2005), while fertile soils usually contain about $100 \mathrm{mg} \mathrm{Pkg}^{-1}$. Many farmers have built up $\mathrm{P}$ reserves in their soils and if mobilised, it would be sufficient for growing crops for decades without applying more $\mathrm{P}$. Therefore, continued application of $\mathrm{P}$ fertiliser to soils already enriched with $\mathrm{P}$ is unsustainable and an economic waste. Evidently, there is a need to improve management of nutrients, particularly to enhance accessibility of the accumulated $\mathrm{P}$ by crops, leading to reduction of inputs, which will subsequently mitigate pollution of the environment. While P application is declining, concern is focused on $\mathrm{P}$ remaining in cultivated soils. Phosphorus not utilised by crops is either leached into groundwater or transported to surface water bodies by surface runoff. Mobilisation and transportation of nutrients from terrestrial systems to groundwater, rivers, lakes and marine environments causes deteriorating water quality and eutrophication. In all countries of Northern Europe, including Alpine areas, agriculture is estimated to be responsible for the greatest contribution of P to waters. Rahm and Danielsson (2007) have suggested that the only significant potential way to reduce the $\mathrm{P}$ load rests on reduction of diffuse (nonpoint source) emissions from agricultural land. Since P in soil is involved in both biological and chemical processes, losses from soils vary considerably over time and between fields. Furthermore, the complexity of these processes and their interactions make $\mathrm{P}$ even more difficult to control than $\mathrm{N}$. Not only are efficient countermeasures and adequate strategies to drastically reduce $\mathrm{P}$ loss from agricultural soils still lacking, but the knowledge basis needed to implement appropriate measures is also rather limited.

Over the last 20 years, the use of plant growthpromoting rhizosphere micro-organisms for sustainable agriculture has tremendously increased in various parts of the world and especially in the EU (Khalid et al. 2004). Soil-born micro-organisms such as bacteria and mycorrhizae fungi, mostly those associated with plants rhizosphere, are able to exert a beneficial effect upon plant growth. Therefore, their use as control agent for agriculture and environment improvement has been a focus of research for some years (Glick 1995; Khalvati et al. 2005; Cozzolino et al. 2010). Higher concentrations of P-solubilising microorganisms have been found in the rhizosphere in comparison with bulk soil, which can be of interest for biogeochemistry and the maintenance of soil health and quality (Jeffries et al. 2003). Phosphate uptake by plants and subsequent growth promotion in plant-soil systems inoculated with P-solubilising micro-organisms are more pronounced when co-inoculated with arbuscular mycorrhizal 
fungi (AMF). AMF are capable of sparingly mobilising soluble inorganic phosphate by the excretion of $\mathrm{H}^{+}$after the utilisation of ammonium ion by the hyphae (Yeo et al. 2001). Mycorrhizal roots can use sources of $P$ in soil that are not available to non-mycorrhizal roots. The main contribution of AMF to the host plant is to reach and deliver $\mathrm{P}$ through their extracortical and extraradical hyphae (Fig. 6), penetrating as much as 5 to $9 \mathrm{~cm}$ into the soil (Khalvati 2005). This involves increased rates of solubilisation of inorganic $\mathrm{P}$ or hydrolysis of organic $\mathrm{P}$ and depends on localised alteration of $\mathrm{pH}$, production of organic anions and of surface or soluble phosphatases. Consequently, it has been possible to calculate that the fungi contribute to about $70-80 \%$ of the $\mathrm{P}$ absorbed by mycorrhizal roots (Li et al. 1991; Tisserant et al. 1993).

In addition to AMF-mediated acquisition, $\mathrm{P}$ can also be very efficiently released by bacteria belonging to the genera Rhizobium, Pseudomonas and spore-forming Bacillus (Rodriguez and Fraga 1999). Such P-solubilising effects have been observed with Sinorhizobium and Rhizobium spp. for the benefit of leguminous plants (Khattak et al. 1991; Halder and Chakrabarty 1993) and for inoculation of soybean with Pseudomonas (Brockwell and Bottomley 1995; Gaind and Gaur 2002). However, there is some circumstantial evidence that development of activity is linked to the presence of arbuscules and transfer of $P$ to the plant. Among the beneficial microbes the multiple interactions between bacteria and fungi may cause a further synergistic effect on the plant growth and fitness, as it has

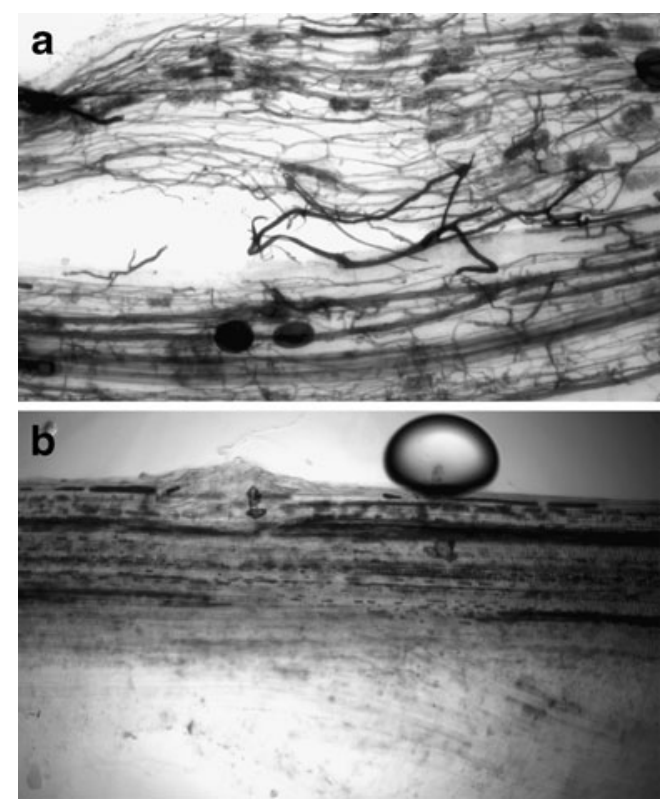

Fig. 6 Roots of barley (Hordeum vulgaris L. cv. Scarlett) inoculated (a) or not (b) with arbuscular mycorrhizal fungi (Glomus intraradices $)$, as viewed under microscope $(\times 100$ magnification). For details of experimentation, see (Khalvati et al. 2005) been demonstrated with combined Azospirillum, Rhizobium and mycorrhizal co-inoculation by Biro et al. (2000).

Mycorrhizae can also reduce the contact of plants with heavy metals and at the same time stimulate their growth. However, most experiments do not consider rhizosphere processes, e.g., the role of mycorrhizae. For example, glomalin-related soil protein (GRSP), a glycoprotein produced by $\mathrm{AMF}$, contributes to the sequestering of $\mathrm{Cu}$ and $\mathrm{Zn}$ in the soil, and the microsite variation of other soil traits $(\mathrm{pH}$, water-stable aggregates, soil organic carbon) affects the heavy metal sequestration by GRSP in polluted soils. The GRSP $-\mathrm{Cu}$ complex can be a substantial pool in the soil and can represent one of the main forms of immobilised $\mathrm{Cu}$, contributing to the chemical stabilisation of contaminated soils through the deposition of enriched $\mathrm{Cu}$ particles. The accumulation of high quantities of GRSP may also contribute to the formation of soil aggregates, even under extreme conditions of acidity and heavy metals availability (Cornejo et al. 2008).

Mycorrhizal fungi do also influence the accumulation of heavy metals by plants (Vivas et al. 2006; Azcón et al. 2009; Pongrac et al. 2009). Plant-associated rhizospheric microorganisms thus play a major role in different biogeochemical processes and in the control of elements solubilisation, bioavailability and phytoextraction (Perriguey et al. 2008; Turnau et al. 2008; Becerra-Castro et al. 2009; Luster et al. 2009; Martinez-Alcala et al. 2009; Wenzel 2009).

At the present time, however, their study and utilisation under real field conditions in Alpine areas are scarce and should be developed, especially in regions impacted by human activities. In the future, such an approach would help improving the quality of Alpine soils containing too much phosphate or toxic metals and cultivating healthy plants for both phytoremediation and food chain safety purposes.

\section{Conclusions, recommendations and perspectives}

Worlwide, including Alpine areas, the controlled use of appropriate plants is destined to play a major role for remediation and restoration of polluted and degraded ecosystems, monitoring and assessment of environmental quality, prevention of landscape degradation and improvement of food quality. The different case studies and approaches mentioned above are promising enough to offer efficient and environment friendly tools to clean up contaminated soils, brownfields and wastewater in the very specific environment and climate of the Alps.

However, each of these goals requires a sound understanding of how plants specifically accumulate or exclude essential elements, toxic metals, phosphate and organic pollutants. Basic knowledge is thus required on the concentration and toxicity of trace elements and xenobiotics in the environment, their bioavailability in the rhizosphere, 
their uptake by roots and translocation to shoot, their detoxification, metabolism and storage. For such a purpose, significant efforts have been carried out over the last decade in different mountainous countries.

One of the most important challenges is now to use basic scientific knowledge to improve the efficiency of phytotechnologies in the field. The dissemination of results, risk assessment, public awareness and acceptance of this green technology, as well as the promotion of networking between scientists, environmental engineers, industrials, stakeholders, end-users, non-governmental organisations and local authorities are major issues that must be tackled to ensure that phytoremediation programmes are correctly and successfully implemented, more precisely under Alpine conditions. It is clear that phytotechnologies do offer promising and sustainable approaches towards environmental remediation, human health and a sustainable development for the 21 st century, in Alpine areas and elsewhere all over the world.

Acknowledgments The authors acknowledge the support of the European project Alps Bio Cluster (Biotech and Medtech in Alpine Space), http://www.alpsbiocluster.eu.

\section{References}

Almendras ML, Carballa M, Diels L, Vanbroekhoven K, Chamy R (2009) Prediction of heavy metals mobility and bioavailability in contaminated soil using sequential extraction and biosensors. J Environ Eng 135:839-844

Antosiewicz DM, Escude-Duran C, Wierzbowska E, Sklodowska A (2008) Indigenous plant species with the potential for the phytoremediation of arsenic and metals contaminated soil. Water Air Soil Pollut 193:197-210

Aubert S (2003) Accumulation and transformation of sulphonated anthraquinones by higher plants: a first step towards the phytotreatment of wastewater from dye and textile industry. Ph. D. thesis, EPFL Nr 2809

Aubert S, Schwitzguébel JP (2002) Separation of sulphonated anthraquinones in various matrices by capillary electrophoresis. Chromatographia 56:693-697

Aubert S, Schwitzguébel JP (2004) Screening of plant species for the phytotreatment of wastewater containing sulphonated anthraquinones. Water Res 38:3569-3575

Azcón R, Medina A, Roldán A, Biró B, Vivas A (2009) Significance of treated agrowaste residue and autochthonous inoculates (arbuscular mycorrhizal fungi and Bacillus cereus) on bacterial community structure and phytoextraction to remediate soils contaminated with heavy metals. Chemosphere 75:327-334

Baker AJM, McGrath SP, Sidoli CMD, Reeves RD (1994) The possibility of in-situ heavy-metal decontamination of polluted soils using crops of metal-accumulating plants. Res Conserv Recycl 11:41-49

Barrutia O, Epelde L, Garcia-Plazaola JI, Garbisu C, Becerril JM (2009) Phytoextraction potential of two Rumex acetosa L. accessions collected from metalliferous and non-metalliferous sites: effect of fertilization. Chemosphere 74:259-264

Becerra-Castro C, Monterroso C, Garcia-Leston M, Prieto-Fernandez A, Acea MJ, Kidd PS (2009) Rhizosphere microbial densities and trace metal tolerance of the nickel hyperaccumulator Alyssum serpyllifolium subsp. lusitanicum. Int J Phytoremediat 11:525-541
Bert V, Seuntjens P, Dejonghe W, Lacherez S, Hoang Thi TT, Vandecasteele B (2009) Phytoremediation as a management option for contaminated sediments in tidal marshes, flood control areas and dredged sediment landfill sites. Environ Sci Pollut Res 16:745-764

Biro B, Koves-Pechy K, Voros I, Takacs T, Eggenberger P, Strasser RJ (2000) Interrelations between Azospirillum and Rhizobium nitrogen-fixers and arbuscular mycorrhizal fungi in the rhizospherenof alfalfa in sterile, AMF-free or normal soil conditions. Appl Soil Ecol 15:159-168

Borin M, Passoni M, Thiene M, Tempesta T (2010) Multiple functions of buffer strips in farming areas. Europ J Agronomy 32:103-111

Brockwell J, Bottomley PJ (1995) Recent advances in inoculant technology and prospects for the future. Soil Biol Biochem 27:683-697

Bulc TG, Ojstrsek A (2008) The use of constructed wetlands for dyerich textile wastewater treatment. J Hazard Mater 155:76-82

Bulc TG, Slak AS (2009) Ecoremediation-a new concept in multifunctional ecosystem technologies for environmental protection. Desalination 246:2-10

Burgos P, Perez-de-Mora A, Madejon P, Cabrera F, Madejon E (2008) Trace elements in wild grasses: a phytoavailability study on a remediated field. Environ Geochem Health 30:109-114

Butcher DJ (2009) Phytoremediation of lead in soil: recent applications and future prospects. Appl Spectrosc Rev 44:123-139

Cheng SP (2003) Effects of heavy metals on plants and resistance mechanisms. Environ Sci Pollut Res 10:256-264

Clemente R, Dickinson NM, Lepp NW (2008) Mobility of metals and metalloids in a multi-element contaminated soil 20 years after cessation of the pollution source activity. Environ Pollut 155:254-261

Comino E, Fiorucci A, Menegatti S, Marocco C (2009) Preliminary test of arsenic and mercury uptake by Poa апnиа. Ecol Eng $35: 343-350$

Cornejo P, Meier S, Borie G, Rillig MC, Borie F (2008) Glomalinrelated soil protein in a Mediterranean ecosystem affected by a copper smelter and its contribution to $\mathrm{Cu}$ and $\mathrm{Zn}$ sequestration. Sci Total Environ 406:154-160

Cozzolino V, Pigna M, Di Meo V, Caporale AG, Violante A (2010) Effects of arbuscular mycorrhizal inoculation and phosphorus supply on the growth of Lactuca sativa L. and arsenic and phosphorus availability in an arsenic polluted soil under nonsterile conditions. Appl Soil Ecol 45:262-268

Denys S, Rollin C, Guillot F, Baroudi H (2006) In-situ phytoremediation of PAHs contaminated soils following a bioremediation treatment. Water Air Soil Pollut Focus 6:299-315

Dessureault-Rompre J, Nowack B, Schulin R, Tercier-Waeber ML, Luster J (2008) Metal solubility and speciation in the rhizosphere of Lupinus albus cluster roots. Environ Sci Technol 42:7146-7151

Dickinson NM, Baker AJM, Doronila A, Laidlaw S, Reeves RD (2009) Phytoremediation of inorganics: realism and synergies. Int J Phytoremediat 11:97-114

Euliss K, Ho CH, Schwab AP, Rock S, Banks MK (2008) Greenhouse and field assessment of phytoremediation for petroleum contaminants in a riparian zone. Bioresour Technol 99:1961-1971

Fässler E, Robinson BH, Stauffer W, Gupta SK, Papritz A, Schulin R (2010) Phytomanagement of metal-contaminated agricultural land using sunflower, maize and tobacco. Agric Ecosyst Environ $136: 49-58$

Fitz WJ, Wenzel WW (2002) Arsenic transformation in the soilrhizosphere-plant system, fundamentals and potential application of phytoremediation. J Biotechnol 99:259-278

French CJ, Dickinson NM, Putwain PF (2006) Woody biomass phytoremediation of contaminated brownfield land. Environ Pollut 141:387-395

Frossard E, Condor LM, Oberson A, Sinaj S, Fardeau JC, Sharply AN (2000) Practical and innovative measures for the control of agricultural P. J Environ Qual 29:15-23 
Gaind S, Gaur AC (2002) Impact of fly ash and phosphate solubilising bacteria on soybean productivity. Bioresour Technol 85:313-315

Gao YZ, Collins CD (2009) Uptake pathways of polycyclic aromatic hydrocarbons in white clover. Environ Sci Technol 43:6190-6195

Gao YZ, Ling W (2006) Comparison for plant uptake of phenanthrene and pyrene from soil and water. Biol Fertil Soils 42:387-394

Garcia G, Zanussi AL, Faz A (2005) Evaluation of heavy metal availability prior to an in situ soil phytoremediation program. Biodegradation 16:187-194

Gaskin SE, Bentham RH (2010) Rhizoremediation of hydrocarbon contaminated soil using Australian native grasses. Sci Total Environ 408:3683-3688

Glick BR (1995) The enhancement of plant growth by free-living bacteria. Can J Microbiol 41:109-117

Grispen VMJ, Nelissen HJM, Verkleij JAC (2006) Phytoextraction with Brassica napus L.: a tool for sustainable management of heavy metal contaminated soils. Environ Pollut 144:77-83

Gurska J, Wang W, Gerhardt KE, Khalid AM, Isherwood DM, Huang XD, Glick BR, Greenberg BM (2009) Three year field test of a plant growth promoting rhizobacteria enhanced phytoremediation system at a land farm for treatment of hydrocarbon waste. Environ Sci Technol 43:4472-4479

Haberl R, Grego S, Langergraber G, Kadlec RH, Cicalini AR, Martins Dias S, Novais JM, Aubert S, Gerth A, Thomas H, Hebner A (2003) Constructed wetlands for the treatment of organic pollutants. J Soils Sediments 3:109-124

Halder AK, Chakrabarty PK (1993) Solubilization of inorganicphosphate by Rhizobium. Folia Microbiol 38:325-330

Hartley W, Lepp NW (2008) Effect of in situ soil amendments on arsenic uptake in successive harvests of ryegrass (Lolium perenne cv Elka) grown in amended As-polluted soils. Env Pollut 156:1030-1040

Hernandez-Allica J, Becerril JM, Garbisu C (2008) Assessment of the phytoextraction potential of high biomass crop plants. Environ Pollut 152:32-40

Huang XD, El-Alawi Y, Penrose DM, Glick BR, Greenberg BM (2004) A multi-process phytoremediation system for removal of polycyclic aromatic hydrocarbons from contaminated soils. Environ Pollut 130:465-476

Huang XD, El-Alawi Y, Gurska J, Glick BR, Greenberg BM (2005) A multi-process phytoremediation system for decontamination of persistent total petroleum hydrocarbons (TPHs) from soils. Microchem J 81:139-147

Imfeld G, Braeckevelt M, Kuschk P, Richnow HH (2009) Monitoring and assessing processes of organic chemicals removal in constructed wetlands. Chemosphere 74:349-362

Jeffries DS, Clair T, Couture S, Dillon P, Dupont J, Keller W, McNicol D, Tuner R, Vet R, Weever R (2003) Assessing recovery of lakes in southeastern Canada from acidic deposition. Ambio 32:176182

Jiang CA, Wu QT, Sterckeman T, Schwartz C, Sirguey C, Ouvrard S, Perriguey J, Morel JL (2010) Co-planting can phytoextract similar amounts of cadmium and zinc to mono-cropping from contaminated soils. Ecol Eng 36:391-395

Keller J, Banks MK, Schwab AP (2008) Effect of soil depth on phytoremediation efficiency for petroleum contaminants. J Environ Sci Health A 43:1-9

Khalid A, Arshad M, Zahir ZA (2004) Screening plant growthpromoting rhizobacteria for improving growth and yield of wheat. J Appl Microbiol 96:473-480

Khalvati MA (2005) Quantification of water uptake of hyphae contribution to barley subjected to drought conditions. Ph.D. Thesis, Technical University of Munich, Germany

Khalvati MA, Hu Y, Mozafar A, Schmidhalter U (2005) Quantification of water uptake by arbuscular mycorrhizal hyphae and its significance for leaf growth, water relations, and gas exchange of barley subjected to drought stress. Plant Biol 7:706-712
Khattak RA, Page AL, Parker DR, Bakhtar D (1991) Accumulation and interaction of arsenic, selenium, molybdenum and phosphorous in alfalfa. J Environ Qual 20:165-168

Kidd PS, Dominguez-Rodriguez MJ, Diez J, Monterroso C (2007) Bioavailability and plant accumulation of heavy metals and phosphorus in agricultural soils amended by long-term application of sewage sludge. Chemosphere 66:1458-1467

Kidd P, Barcelo J, Bernal MP, Navari-Izzo F, Poschenrieder C, Shilev S, Clemente R, Monterroso C (2009) Trace element behaviour at the root-soil interface: implications in phytoremediation. Environ Exp Bot 67:243-259

Komives T, Gullner G, Bittsanszky A, Pascal S, Laurent F (2009) Phytoremediation of persistent organic pollutants. Cereal Res Commun 37:537-540

Kumpiene J, Ore S, Lagerkvist A, Maurice C (2007) Stabilization of $\mathrm{Pb}$ - and $\mathrm{Cu}$-contaminated soil using coal fly ask and peat. Environ Pollut 145:365-373

Li XL, Marschner H, Tabatabai M (1991) Acquisition of phosphorus and copper by VA mycorrhizal hyphae and root-to-shoot transport in white clover. Plant Soil 136:49-57

Lin H, Tao S, Zuo Q, Coveney RM (2007) Uptake of polycyclic aromatic hydrocarbons by maize plants. Environ Pollut 148:614-619

Liste HH, Prutz I (2006) Plant performance, dioxygenase-expressing rhizosphere bacteria, and biodegradation of weathered hydrocarbons in contaminated soil. Chemosphere 62:1411-1420

Liste HH, White JC (2008) Plant hydraulic lift of soil waterimplications for crop production and land restoration. Plant Soil 313:1-17

Luster J, Gottlein A, Nowack B, Sarret G (2009) Sampling, defining, characterizing and modeling the rhizosphere-the soil science tool box. Plant Soil 321:457-482

Marques APGC, Rangel AOSS, Castro PML (2009a) Remediation of heavy metal contaminated soils: phytoremediation as a potentially promising clean-up technology. Crit Rev Environ Sci Technol 39:622-654

Marques APGC, Moreira H, Rangel AOSS, Castro PML (2009b) Arsenic, lead and nickel accumulation in Rubus ulmifolius growing in contaminated soil in Esteiro de Estarreja Portugal. J Hazard Mater 165:174-179

Martinez-Alcala I, Clemente R, Bernal MP (2009) Metal availability and chemical properties in the rhizosphere of Lupinus albus L. growing in a high-metal calcareous soil. Water Air Soil Pollut 201:283-293

Meers E, Van Slycken S, Adriaensen K, Ruttens A, Vangronsveld J, Du Laing G, Witters N, Thewys T, Tack FMG (2010) The use of bio-energy crops (Zea mays) for "phytoattenuation" of heavy metals on moderately contaminated soils: a field experiment. Chemosphere 78:35-41

Memon AR, Schröder P (2009) Metal accumulation in plants and its implication in phytoremediation. Environ Sci Pollut Res 16:162175

Mench M, Schwitzguébel JP, Schröder P, Bert V, Gawronski S, Gupta S (2009) Assessment of successful experiments and limitations of phytotechnologies: contaminant uptake, detoxification and sequestration, and consequences for food safety. Environ Sci Pollut Res 16:876-900

Mench M, Lepp N, Bert V, Schwitzguébel JP, Gawronski SW, Schröder P, Vangronsveld J (2010) Successes and limitations of phytotechnologies at field scale: outcomes, assessment and outlook from COST Action 859. J Soils Sediments 10:1039-1070

Nedunuri KV, Govindaraju RS, Banks MK, Schwab AP, Chen Z (2000) Evaluation of phytoremediation for field-scale degradation of total petroleum hydrocarbons. J Environ Eng 126:483-490

Nehnevajova E, Herzig R, Federer G, Erismann KH, Schwitzguébel JP (2005) Screening of sunflower cultivars for metal phytoextraction in a contaminated field prior to mutagenesis. Int $\mathrm{J}$ Phytoremediat 7:337-349 
Nehnevajova E, Herzig R, Federer G, Erismann KH, Schwitzguébel JP (2007) Chemical mutagenesis - a promising technique to increase metal concentration and extraction in sunflowers. Int $\mathrm{J}$ Phytoremediat 9:149-165

Nehnevajova E, Herzig R, Bourigault C, Bangerter S, Schwitzguébel JP (2009) Stability of enhanced yield and metal uptake by sunflower mutants for improved phytoremediation. Int J Phytoremediat 11:329-346

Onwubuya K, Cundy A, Puschenreiter M, Kumpiene J, Bone B, Greaves J, Teasdale P, Mench M, Tlustos P, Mikahlovsky S, Waite S, Friesl-Hanl MB, Müller I (2009) Developing decision support tools for the selection of "gentle" remediation approaches. Sci Total Environ 407:6132-6142

Otto S, Vianello M, Infantino A, Zanin G, Di Guardo A (2008) Effect of a full-grown vegetative filter strip on herbicide runoff: maintaining of filter capacity over time. Chemosphere 71:74-82

Page V, Schwitzguébel JP (2009a) The role of cytochromes P450 and peroxidases in the detoxification of sulphonated anthraquinones by rhubarb and common sorrel plants cultivated under hydroponic conditions. Environ Sci Pollut Res 16:805-816

Page V, Schwitzguébel JP (2009b) Metabolism of sulphonated anthraquinones in rhubarb, maize and celery: the role of cytochromes P450 and peroxidases. Plant Cell Rep 28:1725-1735

Palmroth MRT, Koskinen PEP, Pichtel J, Vaajasaari K, Joutti A, Tuhkanen TA, Puhakka JA (2006) Field-scale assessment of phytotreatment of soil contaminated with weathered hydrocarbons and heavy metals. J Soils Sediments 6:128-136

Pedron F, Petruzzelli G, Barbafieri M, Tassi E (2009) Strategies to use phytoextraction in very acidic soil contaminated by heavy metals. Chemosphere 75:808-814

Peralta-Videa JR, Gardea-Torresdey JL, Gomez E, Tiemann KJ, Arteaga S, Rascon A, Parsons JG (2001) Uptake and effect of five heavy metals on germination and growth of live alfalfa plant (Medicago sativa) grown in solid media. Bull Environ Contam Toxicol 66:727-737

Perriguey J, Sterckeman T, Morel JL (2008) Effect of rhizosphere and plant-related factors on the cadmium uptake by maize (Zea mays L.). Environ Exp Bot 63:333-341

Plata-Chebbah N (2000) Etude inhérente à un procédé de phytoremédiation de sols contaminés par des hydrocarbures du pétrole. Ph.D. thesis, EPFL Nr 2306

Pongrac P, Sonjak S, Vogel-Mikuš K, Kump P, Nečemer M, Regvar M (2009) Roots of metal hyperaccumulating population of Thlaspi praecox (Brassicaceae) harbour arbuscular mycorrhizal and other fungi under experimental conditions. Int $\mathrm{J}$ Phytoremediat 11:347-359

Quartacci MF, Argilla A, Baker AJM, Navari-Izzo F (2006) Phytoextraction of metals from a multiply contaminated soil by Indian mustard. Chemosphere 63:918-925

Quartacci MF, Irtelli B, Gonnelli C, Gabbrielli R, Navari-Izzo F (2009) Naturally-assisted metal phytoextraction by Brassica carinata: role of root exudates. Environ Pollut 157:2697-2703

Rahm L, Danielsson A (2007) Spatial heterogeneity of nutrients in the Baltic Proper, Baltic Sea. Coastal Self Sci 73:263-278

Remon E, Bouchardon JL, Cornier B, Guy B, Leclerc JC, Faure O (2005) Soil characteristics, heavy metal availability and vegetation recovery at a former metallurgical landfill: implications in risk assessment and site restoration. Environ Pollut 137:316-323

Rezek J, der Wiesche C, Mackova M, Zadrazil F, Macek T (2008) The effect of ryegrass (Lolium perenne) on decrease of PAH content in long term contaminated soil. Chemosphere 70:1603-1608

Robinson BH, Banuelos G, Conesa HM, Evangeliou MWH, Schulin $\mathrm{R}$ (2009) The phytomanagement of trace elements in soil. Crit Rev Plant Sci 28:240-266

Rodriguez H, Fraga R (1999) Phosphate solubilising bacteria and their role in plant growth promotion. Biotechnol Adv 17:319-339
Schwitzguébel JP, Aubert S, Grosse W, Laturnus F (2002) Sulphonated aromatic pollutants - limits of microbial degradability and potential of phytoremediation. Environ Sci Pollut Res 9:62-72

Schwitzguébel JP, Braillard S, Page V, Aubert S (2008) Accumulation and transformation of sulfonated aromatic compounds by higher plantstoward the phytotreatment of wastewater from dye and textile industries. In: Khan NA, Singh S, Umar S (eds) Sulfur assimilation and abiotic stress in plants. Springer, Berlin, pp 335-353

Schwitzguébel JP, Kumpiene J, Comino E, Vanek T (2009) From green to clean: a promising and sustainable approach towards environmental remediation and human health for the $21 \mathrm{st}$ century. Agrochimica 53:209-237

Schwitzguébel JP, Page V, Martins Dias S, Davies L, Vasilyeva G, Strijakova E (2011) Using plants to remove foreign compounds from contaminated water and soil. In: Schröder P, Collins C (eds) Organic xenobiotics and plants: from mode of action to ecophysiology. Springer, Berlin, pp 149-189

Singh BR, Krogstad T, Shivay YS, Shivakumar BG, Bakkegard M (2005) Phosphorus fractionation and sorption in P-enriched soils of Norway. Nutr Cycl Agroecosyst 73:245-256

Tisserant B, Gianinazzi-Pearson V, Gianinazzi S, Gollotte A (1993) In planta histochemical staining of fungal alkaline phosphatase activity for analysis of efficient arbuscular mycorrhizal infections. Mycol Res 97:245-250

Turnau K, Anielska T, Ryszka P, Gawronski S, Ostachowicz B, Jurkiewicz A (2008) Establishment of arbuscular mycorrhizal plants originating from xerothermic grasslands on heavy metal rich industrial wastes - new solution for waste revegetation. Plant Soil 305:267-280

Van Ginneken L, Meers E, Gzisson R, Ruttens A, Elst K, Tack FMG, Vangronsveld J, Diels L, Dejonghe W (2007) Phytoremediation for heavy metal-contaminated soils combined with bioenergy production. J Environ Eng Landscape Manage 15:227-236

Vangronsveld J, Herzig R, Weyens N, Boulet J, Adriaensen K, Ruttens A, Thewys T, Vassilev A, Meers E, Nehnevajova E, van der Lelie D, Mench M (2009) Phytoremediation of contaminated soils and groundwater: lessons from the field. Environ Sci Pollut Res 16:765-794

Verkleij JAC (2008) Mechanisms of metal hypertolerance and (hyper) accumulation in plants. Agrochimica 52:167-188

Vivas A, Biro B, Nemeth T, Barea JM, Azcon R (2006) Nickeltolerant Brevibacillus brevis and arbuscular mycorrhizal fungus can reduce metal acquisition and nickel toxicity effects in plant growing in nickel supplemented soil. Soil Biol Biochem 38:2694-2704

Vymazal J (2009) The use of constructed wetlands with horizontal subsurface flow for various types of wastewater. Ecol Eng 35:1-17

Vymazal J, Kröpfelovà L (2009) Removal of organics in constructed wetlands with horizontal sub-surface flow: a review of the field experience. Sci Total Environ 407:3911-3922

Wenzel WW (2009) Rhizosphere processes and management in plantassisted bioremediation (phytoremediation) of soils. Plant Soil 321:385-408

Xu SY, Chen YX, Lin KF, Chen XC, Lin Q, Li F, Wang ZW (2009) Removal of pyrene from contaminated soils by white clover. Pedosphere 19:265-272

Yeo Q, Li X, Feng G, Christie P (2001) Mobilization of sparingly soluble inorganic phosphates by the external mycelium of an arbuscular mycorrhizal fungus. Plant Soil 230:279-285

Yoon J, Cao X, Zhou Q, Ma LQ (2006) Accumulation of Pb, Cu and $\mathrm{Zn}$ in native plants growing on a contaminated Florida site. Sci Total Environ 368:456-464

Zabłudowska E, Kowalska J, Jedynak Ł, Wojas S, Skłodowska A, Antosiewicz DM (2009) Search for a plant for phytoremediationwhat can we learn from field and hydroponic studies? Chemosphere 77:301-307 